\title{
INITIATION PLANTS AND THEIR ROLE IN TREATMENT IN THE VAUPES REGION, SOUTH AMERICA
}

\author{
Gabriel David Beltrán Zapata ${ }^{1}$, Nohelia Andrea Castro Pineda ${ }^{1}$ \\ ${ }^{1}$ Corporación Comunidades Ecológicas de Colombia (COECO), Cra. 34 no. 10-57, Bogota, Colombia
}

\begin{abstract}
BELTRÁN ZAPATA GABRIEL DAVID, CASTRO PINEDA NOHELIA ANDREA. 2018. Initiation Plants and their Role in Treatment in the Vaupes region, South America. Acta Universitatis Agriculturae et Silviculturae Mendelianae Brunensis, 66(4): 853-857.
\end{abstract}

In this article, we focus on plants used during initiation rites in Colombia. The aim of this paper is to describe the initiation plants of Cubeo and Curripaco people living in the Vaupés region.and explain how their application changed to be therapeutical only with the loss of rich cultural and ritual uses because the rites were abandoned by ethnic groups, who originally performed them. There are described plants of Cubeo and Curripaco people living in the Vaupés region. These ethnic groups are recognized to have an extensive knowledge on medicinal plants, venoms and aphrodisiacs. Finally, we declare that conservation tools and cross cultural research projects are needed to be established to preserve initiation rites for future generations, because they are part of world cultural heritage.

Keywords: initiation plants, treatment, Colombia, Vaupés

\section{INTRODUCTION}

Traditional ecological knowledge on medicinal plants represents a fundamental instrument of indigenous people to prevent and treat diseases. The evolution of traditional medicine has differentiated social and cultural functions of social actors, who perform it. There has been a complex network of traditions developed, including initiation courses and sacred ceremonies. One has to pass through these rites before being accepted and recognized as a healer or shaman. Sacred ceremonies and initiation courses require rigorous diet to aquire the knowledge correctly and to mantain spiritual communication with its owners, ancestors and natural spirits. However, these practice changed a lot in the current period and many of these customs were, if not have been completely abandoned, and have been transformed to have different, mostly therapeutic purpose.

In this article, we focus on the Vaupés region in Colombia, where long-term research was implemented. The aim of this article is to analyze, how initiation plants are currently administered. We have documented and analyzed the initiation process in Cubeo and Curripaco ethnic groups performed during ceremonies as the Jaguars of Yurupary, courses for people to teach them how to be shamans and healers, consisting of diets and sacred plants use. These plants are used to mantain health, organization, harmony in the territory and communication with spiritual beings. Finally, we compare the current situation in Colombia with Peru and South Africa where the use of initiation plants has significant importance in the therapeutic healing process healers undergo and we conclude with recommendations for the preservation of these initiation rites.

\section{MATERIALS AND METHODS}

In Colombia, field-work was done in the Vaupés region, located in the northwestern Amazon. The $99,9 \%$ of this region is declared as a forest reserve (law 2 of 1959) and $77,1 \%$ also as an indigenous reservation (res. no. 0086 1982, 
INCORA). In Vaupés, $85 \%$ of the population is indigenous. $15 \%$ are mestizos or inhabitants of European or African descent. Since 2011, we have recollected data in the Macaquiño community $\left(01^{\circ} 16^{\prime} 01,5^{\prime \prime} \mathrm{N}, \quad 70^{\circ} 06^{\prime} 54,6{ }^{\prime \prime} \mathrm{W}\right)$ from Cubeo and Curripaco shamans that have family relations across all the Vaupés Basin, including brazilian communities.

To recollect the data in Vaupés, participatory research was implemented. This method is based on United Nations guidelines and consists in involving local people as co-researchers in the frame of investigations (Durston and Miranda, 2002). This participatory research gave us an opportunity to work with traditional healers and shamans in the context of their own culture and reproduce their knowledge. The community itself selected four shamans to participate as informants.

Further, ethnographic methods were applied. Semistructured/open interviews and direct/participant observation (Martin, 1995) have been organized to recollect the data on cultural history and plants used in initiation process. From this information some narrations have been compiled (see below).

To enhance our knowledge, four shamans invited us to participate in sacred traditional practices containing diets, preparation and administration of Kuriá yopo (Virola schultesii A. C. Sm.), Coca mambe (Erythroxylum coca var. ipadu Plowman) and Carayurú (Fridericia chica (Bonpl.) L.G. Lohmann).

Plant material was also recollected. Plant specimens were preserved in 70\% ethilic alcohol and stored at National Herbarium of Colombia (COL). Some specimens were determined in the field, others thanks to the published results of previous botanical research in this region (Martínez and Galeano, 2001; Cárdenas, 2007; Cárdenas et al., 2007) or by the comparisson of material deposited in COL and Colombian Amazon Herbarium (COAH).

\section{RESULTS AND DISCUSSION}

\section{Initiation Plants Used in the Vaupés Basin}

The Vaupés Basin, situated at the Colombia-Brazil frontier, is a wild-vurnerable territory of the Northwest Amazon currently inhabited by 32 ethnic groups (Da Cruz, 2007). These groups have been in constant movement and alliances, exchanging materials, technologies, knowledge and women, or even fighting for territory with weapons, poisons and prayers.

Sacred ceremonies (as Yurupary initiation ceremony), where plants used in shamanic initiation are administered, have been shared along the time with occult respect and responsibility, but nowadays this practice is declining identically to Peru. The purpose of this section is to fortify the local and global perception about the traditions and plant use knowledge used by cubeo and curripaco shamans and traditional healers in the Vaupés Basin by documenting their ceremonies.

\section{Yurupary Ceremony: Initiation Process}

The Yurupary ceremony has been practiced by various ethnic groups belonging to Tupí-Guaraní, East Tucano and Arawak linguistic families that live in the Northwest Amazon (Sedlackova, 2000).

In 2011, the traditional knowledge of "jaguar shamans of Yurupary" has been inscribed by the UNESCO on the Representative List of the Intangible Cultural Heritage of Humanity. This ritual represents the origin, growth and maturation of young men. It also designates the process of acquiring spiritual, social, cultural and political knowledge and responsibilities. In the process of connection with supernatural "powers and energies", young men define their position and social role (Osorio, 2006; Harner, 2013).

Yurupary is a word in Yeral or Nengatú language that means "son of the fruit". It also refers to the group of sacred bamboo musical instruments that are used to call participants of the ceremony (Goldman, 1968; Valentine, 1991).

Administration of psychoactive plants, playing sacred instruments, drinking of traditional alcohol-fermented beverages, dancing and prayers can be observed during this ceremony. Only the men can assist in this ceremony and talk about it. Some old shamans, who were our informants, say that in the history, women were responsible for organizing the ceremony. However, just a few women are shamans these days.

Valentine (1991) explained the symbol of sacred flutes used by the Curripaco, related to the mythical ancestral hero Kówai (in Arawak language). Similar figure can be found among the Cubeo, called Kúwai in Tukano language. It is considered to be the source of diseases and maledictions (Goldman, 1968).

Ethnic groups of the Northwestern Amazon refer to different ancestral heroes. During initiation rites or rituals connected to birth and healing, shamans and singers communicate with Kówai or Kúwai and other spirits to modify and control their destructive powers. To do so, men paint their bodies with coffee mud and create representation of tapir (Tapirus terrestris L.).

When a person is sick, some chants and prayers have to be expressed. the prayers call the spirits of the ancestors or the spirits of tobacco (Nicotiana spp.) and the chili pepper (Capsicum spp.). The use of ritual objects that have been given by the first ancestors of each lineage (e.g., sacred plants, poisons, shamanic stones and instruments) is also common among ethnic groups in this ocassion. These objects define the social status and capacity of the group for further exchanging processes and alliances.

\section{Diets}

The diets are part of ritual practices that accompany the initiation and training of young male novice. Nowadays, the young resist to comply the rituals because of the rigorous diets, that begins since the birth and increases before the Yurupary ceremony. 
The diets principally contains restrictions of sexual activity and salt, pepper and warm food consumption. It is permitted to eat some varieties of Squama spp. and yucca (Manihot escuelenta Crantz) in form of flour dissolved in water or starch boiled in water. Also the beginners cannot see directly the women eyes or be close to a woman with menstruation.

\section{Specialized Initiation Courses}

As modern culture, the indigenous science is based on courses with rigorous methods that are used to gain specific knowledge. Each course has multiple tests and proofs. Beginners selected by shamans during the Yurupary ceremony have to prove specific skills: diets, consumption of hallucinogenic plants and prayera represent fundamental practices applied in order to establish contact with ancestors who are considered to be owners of the knowledge on life and nature.

Traditional point of view on specialized initiation courses is expressed in the following narrative of cubeo shaman Rafael Fernández:

"There are different specialized initiation courses. In case of shaman, there are three types: The Tiger, Quartz and Carayuru; each type of graduated shaman has its sacred knowledge, but the teacher has to be old, experienced and respected. Shamans usually choose one or more child and perform specific prayers to make him shaman and live with the family.

Generally, the beginner has to wake up early, at 3 am., have a bath, go fishing and stay in cold places. Then they get back home between 8 and 9 am., after the people have gone for fishing, hunting and agricultural activities, they cannot see the people and family because they cannot stay in noisy places. It is dangerous for them. During the day, they have to snuff yopo (Virola species) and acquire knowledge from the shaman. The course takes six months and not everyone is able to finish it.

The first level of the course takes three months and it is focused on specifical knowledge and power. It teaches the extraction of the disease by the mouth. The second one teaches, how to spit water (a kind of healing tradition to cure diseases with water). When the beginners start, they have to cut the leaves of a special tree used for knitting family baskets.

For example, if tomorrow the shaman is going to provide the first yopo to the beginners, he has to cut the tree and then the first level begins. Each month or two, the beginner has to see how is the tree. When the plant has five leaves, the level is in its half. When the beginner finshes the course, the tree has to be tall and two leaves have to fall to the ground. At this moment, the beginner starts to be a shaman.

Beginners that have the ability to be strong shamans, they have to approve the final test after 6 months that consist in placing of a peashooter arrow in the middle of a big trunk or woody cup, and then change its position without touching it".

\section{Sacred Plants Used in Initiation Practices}

Sacred plants play an important role in initiation practices. In various rituals, fermented fruit beverages and psychotropic plants are processed.
The fermented beverages are called generally chicha and are prepared from different varieties of yucca (Manihot spp.), corn (Zea spp.), ñame (Dioscorea spp.), mirití palm fruits (Mauritia flexuosa L.f.), pupuña palm fruits (Bactris gasipaes HBK), sweet batata (Ipomea batatas (L.) Lam.), and others.

Psychoactive plants, e.g. yagé (Banisteriopsis caapi (Spr. Ex Griesb.) Morton), kuriá yopo (Virola spp.), tobacco powder yopo (Nicotiana spp.), Carayurú (Fridericia chica (Bonpl.) L.G. Lohmann), and the sweet coca (Erythroxylum coca Lam. var ipadu Plowman) are administered for the prevention of diseases (Briceño Robles, 2016).

If above mentioned plants produce vomiting during the ritual, it is a sign of healing and cleaning of the body. During the ceremonies, people are used to drink emetic beverages and do cleaning baths based on plants as Stizophyllum riparium (Kunth) Sandwith and Monopteryx uaucu Spruce ex Benth. that fortify the body and spirit and help to not become drunk with chicha during the ceremonies; the bath based on Abarema auriculata (Benth.) Barneby and J.W. Grimes is performed during the Yurupary ceremony as well.

\section{Kuriá Yopo: Sacred Psychoactive Plant for Divination and Healing}

In Cubeo, Kuriá refers to a preparation made from the Virola spps. bark latex (Schultes and Raffauf, 1990). Kuria is a psychoactive substance used by shamans during healing and divination rituals. It is also applied in the initiation courses. According to shamans, the Kuriá rituals require special diet before the powder inhalation. The shaman begins to shake sacred maracas and the beginner has to look at the clouds in the sky and interpret its movements and messages he receives at that moment from ancestors. Currently, the use of this substance is scarce and the knowledge of its preparation is disappearing.

\section{Carayurú (Mujamu): Tincture for Spiritual Protection}

In Cubeo, Carayurú (or Mujamu) is a substance that has an important role in the indigenous communities of Northern Amazon in the prevention and protection against diseases, difficult situations and maledictions. Before its application, there has to be prayers performed over Carayurú by an experienced shaman or healer.

According to our informants, Carayurú is the ID of the person in the jungle (ID means presence of the spirit in the jungle). The substance is perceived as an evil or dangerous spirit from the jungle that protects people from diseases and animal attacks, especially from jaguars.

In traditional rituals and ceremonies of ethnic groups of northern Amazonia as Yurupary, Dabucurí and others, people always use this protection. The substance facilitates communication with spiritual world.

The principal compound of Carayurú comes from the plant species Fridericia chica. This liana 
is not common in the tropical rain forest, most of the times it is cultivated near houses or in the field among another crops. The compound is commonly used, but not everyone knows how to prepare it because the preparation is very difficult. There are other admixtures used in the Carayurú preparation, the bark of Mouriri nigra (DC.) Morley (Mujaje-tiki) to thicken it, and some indet. fabaceous species (Jitá-miuke) that produces a soap.

\section{Coca Mambe: Medicinal, Spiritual and Stimulant Preparation}

Mambe is a preparation from the coca plant (Erythroxylum spp.). It is a powder that has been used in the most of indigenous cultures in the Amazon and Andes as a stimulant to resist in the long periods of hard working (Granda Cruz,
Rosero and Rosero, 2015). It also has medicinal uses. There is an infusion prepared from the coca leaves that is administered in stomach pains and disorders (Schultes and Raffauf, 1990).

The Erythroxylum genus contains almost 250 species of South-American origin. There are two species widely cultivated in the Amazon, E. coca Lam. and E. novogranatensis (D. Morris) Hieron (Plowman, 1985).

Mambe is principally prepared from the species of E. coca var ipadu Plowman (in Cubeo called karica-pato). Plowman (1985) discovered that the origin of this subspecies is in the Northern Amazon. The preparation of mambe requires a lot of practice because it is easy to burn the leaves or put more Guarumo ash (Cecropia angustifolia Trécul) than it is necessary.

\section{CONCLUSION}

Nowadays the application of initiation plants in Vaupes region has changed from cultural and therapeutical use to be therapeutical only, because most of the rites were abandoned by ethnic groups, who originally performed them. The cultural significance of healing plants have been affected by different historical processes where modern customs have dominated over traditional aspects. These historical events are related to rubber extraction, drug and fur trafficking, cocaine production, and modern political corruption.

Some healing and cultural rites are preserved with all the traditional protocols. In comparison to the initiation plant use in the Vaupés region, in Peru they are sometimes used in therapy. In Takiwasi, Center for Rehabilitation of Drug Addicts and for Research on Traditional Medicines (Tarapoto, San Martín), indigenous medicine with psychotherapy is combined in the the therapeutic program. Inpatients stay in the center for 9 months and pass through various procedures that are based on administration of herbal preparations. One of them is so-called purgahuasca, thin decoction from Banisteriopsis caapi and Diplopterys cabrerana, originally used during inititation rites of the Awajún people (Horák, 2013).

Sobiecki (2014: 164) describes that there appears to be a common sequence of psychoactive initiation plants being used both by South African traditional healers and curandero healers in South America. Hehas hypothesized that this could indicate a cross cultural technology of using psychoactive initiation plants both in the South African and South American traditional medicine systems, as a means of treating and healing psycho-spiritual illness and disease. This is being currently investigated with the establishment of the cross- cultural research project called the Khanyisa Healing Garden project to study, record and publish on initiation plant use between the regions, that may yield significant findings that could further our undestanding of the healing of consciosuness.

\section{REFERENCES}

BRICEÑO ROBLES, M. S. 2015. La resonancia de la vida. Anotaciones sobre la comprensión del espacio sonoro en una ceremonia de yajé en Colombia. In: BRABEC DE MORI, B., LEWY, M. and GARCÍA, M. A. (Eds.). Sudamérica y sus mundos audibles. Cosmologías y prácticas sonoras de los pueblos indígenas. Berlin: Gebr. Mann Verlag, pp. 167-181.

DA CRUZ, H. 2007. Etnoecología y desarrollo sostenible. In: ESPINAR, C. (Ed.). Etnoecología y desarrollo sostenible. Madrid, Spain: Temper, pp. 5-20.

GRANDA CRUZ, L., ROSERO, M. G. and ROSERO, A. 2015. Plantas medicinales de la región Andina tropical. Quinoa (Chenopodium quinoa Willd.) y coca (Erythroxylum sp.), tesoros milenarios para tratamiento medicinal. In: HORÁK, M. (Ed.). Etnobotánica y fitoterapia en América. Brno: Mendel University in Brno, pp. 76-96.

GOLDMAN, I. 1968. Los Cubeo: indios del noreste del Amazonas. México: Instituto Indigenista Interamericano. Ed. Esp. 49.

GÓMEZ, A. and GUEVARA, J. 2008. Adaptación al cambio climático: De los fríos y los calores en los Andes. Experiencias de adaptación tecnológica en siete zonas rurales del Perú. Lima: Soluciones Prácticas.

HARNER, M. 2013. Mysteries of the Jaguar Shamans of the Northwest Amazon. Lincoln, NE: University of Nebraska Press. 
HORÁK, M. 2013. The house of song. Rehabilitation of drug addicts by the traditional indigenous medicine of the Peruvian Amazon. Brno: Mendel University in Brno.

KHANYISA HEALING GARDEN. 2013. Khanyisa Healing Garden. [Online]. Available at: http://www. khanyisagarden.co.za [Accessed: 2018, January 15].

MADER, E. 1999. Metamorfosis del poder: Persona, mito y visión en la sociedad Shuar y Achuar. Quito: Abya-Yala.

NARBY, J. and HUXLEY, F. 2004. Shamans through time. 500 years on the path to knowledge. New York, NY: Jeremy P. Tarcher/Penguin.

OSORIO, B. 2006. El mito de Yurupary: memoria ancestral como resistencia histórica. Revista de Estudios Sociales, 23: 105-111.

SEDLACKOVA, R. 2000. El mito amazónico de Yurupary como obraliteraria. Master's Thesis. Brno, Czech Republic: Masaryk University in Brno, Faculty of Arts, Department of Romance Languages and Literatures.

PLOWMAN, T. 1985. Coca chewing and the botanical origins of Coca (Erythroxylum spp.) in South America. In: PACINI, D. and FRANQUEMONT, C. (Eds.). Coca and cocaine: Effects on people and policy in Latin America. Proceedings of the Conference The Coca Leaf and Its Derivatives-Biology, Society and Policy. Cultural Survival, Inc. \& LASP, pp. 5-33.

SCHULTES, R. E. and RAFFAUF, R. 1990. The healing forest: Medicinal and toxic plants of the Northwest Amazonia. Wilshire, Portland, OR: Dioscorides Press.

UNODC. 2015. Monitoreo de cultivos de coca 2014. UNODC. [Online]. Available at: http://bit.ly/21Uq1Ok [Accessed: 2018, January 15].

SOBIECKI, J. F. 2014. Southern Africa: The Forgotten Cradle of Psychoactive Healing Plants. In: HORÁK, M., RŮŽIČKOVÁ, G., KOCOURKOVÁ, B., SAPÁKOVÁ, E., KAVENSKÁ, V., GRANDA CRUZ, L., ŠKRABÁKOVÁ, L., TOURNON, J., ROSERO ALPALA, M. G., FORERO PINTO, L. E., ROSERO, A., CASTRO PINEDA, N. A., BELTRÁN ZAPATA, G. D., HALBICH, M., MINERO ORTEGA, F., SOBIECKI, J. F. and AMIROVA, E. A Reader in Ethnobotany and Phytotherapy. Folia Universitatis Agriculturae et Silviculturae Mendelianae Brunensis. Brno: Mendel University.

VALENTINE, P. 1991. Curripaco social organization: A study in history, kinship, and marriage in the Upper Río Negro Valley. Ph.D. Thesis. Michigan, MI: The Pennsylvania State University.

Gabriel David Beltrán Zapata: gdbeltranz@gmail.com

Nohelia Andrea Castro Pineda: noheliaacastrop@gmail.com 